\title{
COMPETITIVENESS OF METALLURGICAL ENTERPRISES UNDER THE CRISIS CONDITIONS
}

\author{
Bonchenkova V.A. ${ }^{1}$, Detkov A.A. ${ }^{2}$, Guseva S.Y. ${ }^{3}$, Zhihalov P.S. ${ }^{4}$ \\ Email: Bonchenkova1796@scientifictext.ru
}

\author{
${ }^{1}$ Bonchenkova Vitalina Aleksandrovna - student; \\ ${ }^{2}$ Detkov Aleksandr Aleksandrovich - student; \\ ${ }^{3}$ Guseva Svetlana Yuryevna - student; \\ ${ }^{4}$ Zhihalov Pavel Sergeevich - student, \\ DEPARTMENT "ECONOMICS AND MANAGEMENT OF BUSINESS PROCESSES, \\ FACULTY OF FULL-TIME EDUCATION, \\ FEDERAL STATE AUTONOMOUS EDUCATIONAL INSTITUTION OF HIGHER EDUCATION S \\ IBERIAN FEDERAL UNIVERSITY \\ SCHOOL OF BUSINESS PROCESSES MANAGEMENT AND ECONOMICS, \\ KRASNOYARSK
}

\begin{abstract}
: metallurgy has always been and is one of the strategically important branches of the heavy industry, both in Russia and in other countries of the world. This is due to the fact that its products serve as a base for other sectors of the economy. Secondly, the production of the Russian metallurgical complex is a significant item of exports, but despite such a significant impact on the Russian economy, metallurgy behaves unstably. The article analyzes the behavior of the metallurgical industry under the crisis condition with the help of statistical methodology. The authors conclude that Russia should develop and fund innovative activity in the metallurgical industry. Furthermore, Russia needs to develop other priorities for reducing the risks of production and increase competitiveness industry under the crisis condition.
\end{abstract}

Keywords: metallurgical industry, investments, innovations, economic crisis, Russia, Krasnoyarsk region.

\section{КОНКУРЕНТОСПОСОБНОСТЬ МЕТАЛЛУРГИЧЕСКИХ ПРЕДПРИЯТИЙ В УСЛОВИЯХ КРИЗИСА}

\section{Бонченкова В.А. ${ }^{1}$, Детков А.А. ${ }^{2}$, Гусева С.Ю. ${ }^{3}$, Жихалов П.С. ${ }^{4}$}

\author{
${ }^{1}$ Бонченкова Виталина Александровна - студент; \\ ${ }^{2}$ Детков Александр Александрович - студент; \\ ${ }^{3}$ Гусева Светлана Юрьевна - студент; \\ ${ }_{4}^{4}$ Жихалов Павел Сергеевич - студент, \\ кафедра экономики и управления бизнес-проиессами, факультет очного обучения, \\ Федеральное государственное автономное образовательное учреждение высшего образования \\ Сибирский федеральный университет \\ Институт управления бизнес-процессами и экономикой, \\ г. Красноярск
}

\begin{abstract}
Аннотация: металлургия всегда являлась и является одной из стратегически важных отраслей тяжелой индустрии, как в России, так и в других странах мира. Это связано, во-первых, с тем, что ее продукиия служси базой для других отраслей экономики. Во-вторых, продукиия российского металлургического комплекса является значимой статьей ее экспорта, но, несмотря на столь значимое место в экономике России, металлургия ведет себя нестабильно. В статье анализируется поведение металлургической промышленности в условиях кризиса на основании статистических данных. Авторы делают вывод, что Россия должна развивать и финансировать инновачионную деятельность в металлургической промышленности. Кроме того, России необходимо разработать другие приоритеть для снижения рисков снижения производства и конкурентоспособности в условиях кризиса.

Ключевые слова: металлургическая промыциленность, инвестищии, инновачии, экономический кризис, Россия, Красноярский край.

UDC 330.111 .8

Nowadays, Russian metallurgical complex is one of the most developed and important basic segment of national economy. In general in the Russian Federation there are about 2800 various enterprises of metallurgical profile. The efficient development of a metallurgical complex is achieved due to the export-oriented direction (at some directions the share of export reaches $80-90 \%$ ), and the creation of large business groups of holding type.

In this research, the history of the metallurgical industry development in Russia is considered for the last 15 years.
\end{abstract}


In the period 2000-2007 the global market economic indicators of the non-ferrous metals industry were at a high level. In this period the annual growth rates at the non-ferrous metals enterprises contributed to the double increase of exports.

However in 2007, financial crisis (economic cycle trough) that began in the United States as the mortgage crisis was reflected in the Russian national economy. In 2008 - 2009 a number of key problems which undoubtedly influence on the Russian industrial production including metallurgical branch in general could be observed: a decrease in investment activity, an acceleration of capital outflow, an insufficient financing, high costs of the electric power and transport, high tax rates and rates of refinancing; a decrease in profitability of production due to strengthening of the Russian currency. A number of these problems have affected on nonferrous metals consumption considerably. It was significantly lower than in other more developed European and American countries.

For ensuring competitiveness in the conditions of crisis many national non-ferrous metals enterprises have opted for the way of merging and the establishment of holding companies, so, for example, there was a merge of the "RUSAL" company and "Sual" group of companies, JSC «Uralskaya folga». The alliance formed "The combined company - Russian Aluminum" and the Swiss Glencore International AG - Swiss trading company, one of the world's largest suppliers of commodities and rare-earth materials.

In addition, a number of the industries, with outdated material base, started the production modernization, not only at the expense of profit, but also at the expense of the obtained credits thanks to which positive tendencies of development are observed subsequently.

So, since 2010, the situation has been developing in favor of producers in the world market of non-ferrous metals. Among the basic metals the nickel had the highest price in the first quarter. The market value of the metal has increased by 35\%. A key factor in the growth of nickel has been a recovery in demand for stainless steel in the manufacture of which uses about $60 \%$ of world's nickel production. Copper prices have shown results much below than nickel, but too had a positive gain [5]. The price of gold is similarly rising, reaching $\$ 1,350$ per ounce. In this period the increase in demand was due to the growth rates of construction in the residential sector in big cities, the petroleum refining industry and related engineering industry.

The Crimea annexation to Russia was the reason for Europe and the USA's sanctions imposition, and then a new round of economic crisis began (late 2014 - early 2015), which led to the non-ferrous metals production decrease. So, for 11 months of 2015 the production of non-ferrous metals in Russia decreased by $7.7 \%$ compared to the same period last year [6]. The decrease is mainly determined by the finished products manufacturing falling, as well as the demand going down. Less metal is bought by builders and automakers within the country, and trading with long-term foreign partners is shrinking. Betting on China has not justified either. Now there is an excess of its own steel. Moreover, the loaned MMC companies found out that the decline in global commodity prices was often higher than the decline of the dollar against the ruble.

In the period 2014-2016, the government has been taking anti-crisis measures for the quickest recovery (debt restructuring with partial replacement of western loans by the Russian ones). However, these measures do not seem sufficient, that means poor impact of public finances on the non-ferrous metals industry.

So, in the Krasnoyarsk Territory, metallurgy is the main metallurgical industry. H. Zubarevich said the metallurgical complex is controversial, and she examined the dynamics of the metallurgical industry in the periods of crisis 90s, 2007 and 2014 in her speech - "The crisis in Russia - a regional projection: what to expect and what to prepare" [8]. We agree with her point of view, but we do not know the truth - "We used to work a conservative or metallurgical complex makes a profit actually."

The Krasnoyarsk region approved an innovative strategy for the period up to 2030 in 2012. Acts came into force in 2013, because the implementation requires waiting for a while. This project had a lot of advantages and disadvantages. Currency crisis occurred in early 2014. It had an influence on reducing investments. This crisis was founded on innovation that contributed to an increase in investments in 2015.

Dynamics of investments in the metallurgical industry for 2008 - 2015 in the Krasnoyarsk Territory is shown in a diagram 1 (Krasnoyarskstat). 
1) Investments in the metallurgical industry of the Krasnoyarsk region

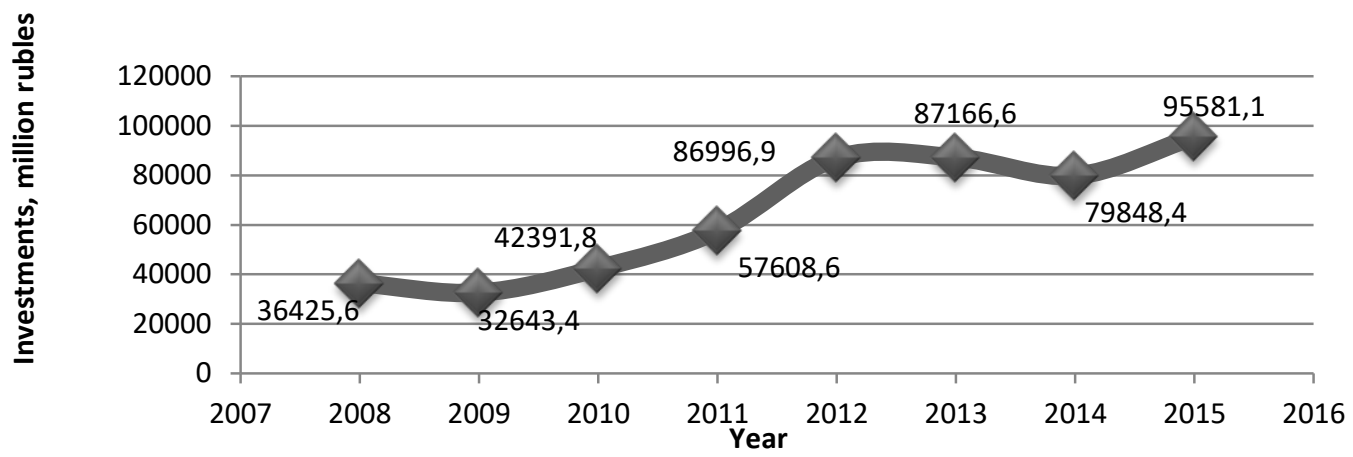

Fig. 1. Investments in the metallurgical industry of the Krasnoyarsk region

Government has always invested metallurgical industry, but it does not achieve the desired results during the crisis 2008-2009 (a diagram 2). This is due to a decrease in the amount of shipped goods and the reduction of investments. The government seeks to stabilize the metallurgical industry due to additional investments in a period after the crisis. But this industry has proved more resilient to the unstable economic situation 2014-2015, compared with the previous crises.

2) The amount of shipped goods metallurgical industry of Russia

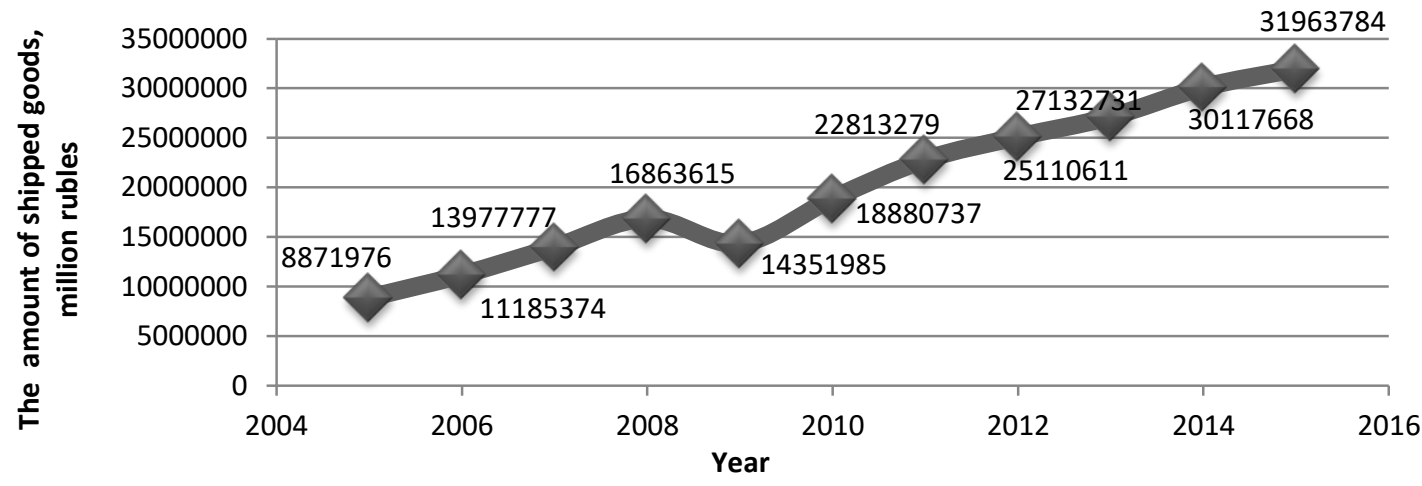

Fig. 2. The amount of shipped goods metallurgical industry of Russia

The percentage of the metallurgical industry in the GRP of the Krasnoyarsk region was reduced (a diagram 3). This industry is unstable, so it is necessary to consider the revision of priorities to improve the competitiveness of the region.

3) The percentage of the metallurgical industry in the GRP of the Krasnoyarsk region



Fig. 3. Diagram - The percentage of the metallurgical industryin the GRP of the Krasnoyarsk region

Metallurgy suffered at the time of crisis of 2008-2009. Unmet need for transition to a new stage of development through the development of information and innovative technologies is one of the reasons for the deterioration of industry performance in this period. $[2,130]$ But the metallurgical industry continued to operate and to sell almost the same amount and investments have increased significantly in the $2014-2015$. 
«We are investing money in the metals industry, because it is a habit or is it really necessary?».But how then to be with the statistics that show that metallurgy behave ambiguously in crisis.

There are two ways of developing this situation. The first - the government needs to continue to invest in the development of metallurgy in the same way, but then it is necessary to radically change the approach to the metallurgical industry, and do not invest in an increase in the scale of production, and the development of the innovation environment. Perhaps the existing metallurgical complex technologies also need to change, which will lead to the creation of effective metallurgical production. Or maybe is it necessary to consider the priorities of other investment objects, which will serve as a guarantor of stable development of not only the region but also the whole country $[1,41]$.

The Russian economy and particularly non-ferrous metals industry analysis has revealed negative trends and systemic problems of the industry needed to be solved in the nearest future. Among them:

- The certain types of raw materials restriction (for example, only 5\% of the world's bauxite reserves are located in the territory of Russia). New fields of iron ore, coking coal have been involved to use.

- Lack of technical and technological level of production on a number of metallurgical enterprises, especially in the mining sector;

- Low perviousness of enterprises to technological innovations' implementation, primarily domestic;

- Increased material, electricity production capacity (for example, the costs of aluminum production are about $30 \%$ of its production cost) transport costs;

- The lack of the metallurgical production competitiveness and the high proportion of low-grade processing exports (mainly raw materials and semi-finished products) [2, 93];

- Decline in world prices for all kinds of non-ferrous metals, the overall production and its consumption reduction.

The concept of development of the industry in general and the concept of development in directions can have a significant influence on the way out of crisis (economic cycle trough) and the definition of priorities. The problems which will need to be resolved:

- Increasing government involvement in the formation of the demand level (government orders);

- Further modernization of industries, the implementation of investment programs aimed at improving the competitiveness and development of new kinds of metallurgical products, the innovation component of the development of production increasing, the intellectualization (automation and robotics);

- The resource base revision, the development of deposits must be based not only on the problem of raw materials for the primary production of any metals, but also on the creation of related technologies and industries, and the production of multi-component materials: nano-products, bi-metal;

- Creation of scientific-innovative centers and technology clusters to meet the needs of non-ferrous metallurgy and related brunches - energy, mechanical engineering, mining industry, as well as the production of finished products;

- Creation of conditions for increasing the demand for the non-ferrous metal products, creation of new small and medium-sized metal processing enterprises, allowing to reorient production quickly to implement the requirements of the market, meet the needs of the national economy;

- Reduction of energy consumption due to energy-saving technologies for the production and use of energy-saving equipment;

- Increasing the purchasing power of the population (construction and automobile);

Therefore, the metallurgy future in modern conditions will be largely determined by the rate of related industries modernization, it is directly connected with the developed innovation and technology and investment framework creation, project backlogs, and thus the metallurgy possibilities to meet future demand.

\section{References}

1. Bonchenkova V.A., Detkov A.A., Nurieva E.V. (2016). Increasing competitiveness through a systematic construction of a sustainable business. The Way of Science, № 7 (29). P. 39 - 43.

2. Bonchenkova V.A., Nurieva E.V. (2016). Transaction costs and Information Economic System. Fundamental and applied science today. № 7. P. $129-131$.

3. Romanova O.A., Selivanov E.N., Chenchevich S.G. (2012). The possibilities and limitations of the modernization of the regional metallurgical complex. The region's economy. № 4. P. $93-94$

4. Non-ferrous metallurgy. Stabilization of prices near current levels. [Electronic resource]. URL: http://www.promweekly.ru/2010-18-6.php/ (date of access: 27.02.17).

5. Russia has reduced the production of non-ferrous metals. [Electronic resource]. URL: http://www.steelland.ru/news/nonferrousmetallurgy/6429.html/ (date of access: 16.03.17).

6. Zubarevich N.V. The crisis in Russia - a regional projection: what to expect and what to prepare. URL: http://www.vsluh.ru/longreads/106/_(date of access: 02.03.17). 